
License. Which Permits unrestricted use, distrubution, and reproduction in any medium, provided the original work is properly cited

\title{
Hubungan Presiden Dan Dewan Perwakilan Rakyat Pasca Amendemen Perspektif Teori Constitutional Retrogression
}

\author{
Ilham Habiburohman \\ Fakultas Hukum Universitas Padjadjaran Bandung Jawa Barat Indonesia \\ Jln. Dipatiukur No. 35 Bandung 40132 Jawa Barat Indonesia \\ ilham049@gmail.com
}

Received: 21 Juli 2020; Accepted: 20 Januari 2021; Published: 16 Maret 2021

DOI: 10.20885/iustum.vol28.iss1.art2

\begin{abstract}
The term Constitutional Retrogression was introduced by Aziz Huq and Tom Ginsburg to identify regress of the constitution, given that the constitution is formed as a safeguard for democracy. This identification is based on three basic principles of democracy, namely, competitive elections, freedom of speech and assembly and the quality of the law. In recent years, proposals for government regulations to replace laws submitted by the President have received the blessing of the House of Representatives (DPR). Whereas in substance it is still considered problematic; such as the promulgation of Perppu No. 1 of 2017 on Social Organizations. This study uses a normative juridical method with a statutory and conceptual approach. The results of the study conclude that the relationship between the President and the DPR after the amendment to the 1945 Constitution has indicated Constitutional Retrogression, hence this study proposes several preventive measures, first, amending the regulations on the presidential threshold; second, elections in a multiparty system are held in a proportional system with an open list approach; third, the Constitutional Court must be an impartial institution to mediate between the President and the DPR, which is prone to causing arbitrariness in order to avoid abuse and regress of the constitution.
\end{abstract}

Key Words: Constitutional regressions; DPR; President; relationship

\section{Abstrak}

Terminologi Constitutional Retrogression diperkenalkan oleh Aziz Huq dan Tom Ginsburg untuk mengidentifikasi kemunduran konstitusi, mengingat bahwa konstitusi dibentuk sebagai safeguard demokrasi. Identifikasi tersebut berdasar pada tiga prinsip dasar demokrasi yaitu, pemilihan yang kompetitif, kebebasan berbicara dan berkumpul serta kualitas hukum. Beberapa tahun terakhir usulan peraturan pemerintah pengganti undang-undang yang diajukan oleh Presiden dengan sigap mendapat restu dari DPR. Padahal secara subtansi dinilai masih bermasalah; seperti diundangkanya Perppu No. 1 Tahun 2017 tentang Organisasi kemasyarakatan. Penelitian ini menggunakan metode yuridis normatif dengan pendekatan perundang-undangan dan konseptual. Hasil penelitian menyimpulkan bahwa hubungan antara Presiden dan DPR pasca amendemen UUD 1945 telah terjadi Constitutional Retrogression, sehingga penelitian ini mengusulkan beberapa upaya pencegahan, pertama, membenahi regulasi mengenai ambang batas pencalonan presiden (presidential threshold)); kedua, pemilu dalam sistem multipartai diselenggarakan dengan sistem proporsional dengan daftar terbuka; ketiga, MK harus menjadi lembaga yang imparsial untuk menengahi hubungan Presiden dan DPR yang rentan menimbulkan kesewenang-wenangan guna menghindari penyalahgunaan serta kemunduran konstitusi.

Kata-kata Kunci : DPR; hubungan; kemunduran konstitusi; presiden 


\section{Pendahuluan}

Negara hukum tentu berkaitan dengan kekuasaan. Kekuasaan berkaitan pula dengan konstitusi, karena semua konstitusi selalu menjadikan kekuasaan sebagai pusat perhatian, sebab kekuasaan itu memang perlu diatur dan dibatasi sebagaimana mestinya. ${ }^{1}$ Pembatasan kekuasaan pada umumnya dianggap merupakan corak konstitusi. Konstitusionalisme seperti yang dikemukakan oleh Friedrich oleh karenanya didefiniskan sebagai "an institusionalised system of effective, regularised restraints upon govermental action" (suatu sistem yang terlembagakan, menyangkut pembatasan yang efektif dan teratur terhadap tindakan-tindakan pemerintah). ${ }^{2}$

Pemerintahan konstitusional memiliki beberapa elemen dasar. Berkenaan dengan hal tersebut, Pan Mohammad Faiz ${ }^{3}$ menjabarkan para cendekiawan seperti Giovani Sartori, Louis Henkin, Charles Fombad, Hilaire Barnet dan Scott Guy, masing-masing memiliki perspektif yang berbeda (tentang nilai dasar pemerintahan konstitusional). Namun diantara mereka terdapat sebagian besar persamaan mengenai elemen dasar pemerintahan konstitusional, yaitu: ${ }^{4}(1)$ prinsip pemisahan kekuasaan (separation of power), (2) prinsip negara hukum (rule of law), (3) prinsip demokrasi perwakilan (representative democracy), dan (4) prinsip perlindungan hak dan kebebasan dasar (protection of fundamental rights and freedoms).

Perbandingan hukum-hukum konstitusi di berbagai negara, sehubungan dengan bagaimana konstitusi dibentuk dan digunakan untuk melindungi tatanan demokrasi menjadi isu penting. Isu ini berkaitan erat dengan masifnya penurunan kualitas demokrasi di dunia. ${ }^{5}$ Konstitusi mestinya mengandung prinsip "kedaulatan rakyat" sekaligus "kedaulatan hukum" secara beriringan sebagai dua sisi mata uang yang sama agar dapat mewujudkan negara hukum yang demokratis (democratische rechtstaat). 6 Penurunan konstitusi bisa disebabkan hlm. 30 .

${ }^{1}$ Jimly Asshiddiqie, Konstitusi dan Konstitusionalisme Indonesia, Cetakan ketiga, Sinar Grafika, Jakarta, 2014,

${ }^{2}$ Ibid.

${ }^{3}$ Pan Mohammad Faiz, "Memaknai Salus populi Suprema Lex", Majalah Konstitusi, No. 159, Mei 2020, hlm. 68 .

${ }^{4}$ Ibid.

5 A. Satrio, "Constitutional Retrogression in Indonesia under Presiden Joko widodo's Goverment; What can The constitutional court do?”, Constitutional Review Vol. 4 No. 2, Desember 2018, hlm. 272. hlm. 58 .

${ }^{6}$ Jimly Asshiddiqie, Konstitusi dan Konstitusionalisme Indonesia, Cetakan kedua, Sinar Grafika, Jakarta, 2010, 
karena negara kehilangan salah satu atau dua prinsip wajib tersebut. Secara dzahir konstitusi mungkin tidak berubah, namun dalam praktik, terjadi banyak penyalahgunaan penafsiran dan implementasi sesuai kehendak penguasa.

Terhadap kekuasaan pemerintah, Leonard R. Sorenson membuat premis bahwa ancaman paling mendasar bagi rakyat adalah pemerintah dengan kekuasaan terlalu kuat.7 Sebaliknya, pelindungan bagi rakyat yang paling mendasar adalah pemerintah yang terbatas kekuasaannya (limited government). Pembatasan ini biasanya dituangkan di dalam konstitusi. Namun, sebagaimana yang disampaikan oleh Suri Ratnapala, setiap negara di dunia mengklaim memiliki konstitusi, tetapi hanya sebagian saja yang memiliki pemerintahan konstitusional karena pembatasan kekuasaan sejatinya tidak sekadar tertulis di atas kertas, namun harus tersedia mekanisme yang jelas menegakan ketentuan konstitusinya. ${ }^{8}$

Freedom house menghitung dalam 12 tahun berturut turut negara-negara "menderita" penurunan kualitas demokrasi melebihi jumlah yang mendaftar. ${ }^{9}$ Economist Intelligence Unit menyebut 89 negara mengalami penurunan demokrasi sementara hanya 27 negara yang meningkat pada 2017.10 Pada 2018 Bertlesmann Transmormation Index menemukan kualitas demokrasi mengalami penurunan pada level terendah dalam 12 tahun terakhir. ${ }^{11}$

Fenomena tersebut bukan terfokus pada seberapa banyak negara yang mengalami degradasi demokrasi, namun yang menjadi perhatian ialah bagaimana degradasi itu terjadi. Beda halnya dengan otoritarianisme di masa lalu yang mengandalkan cara-cara extreme untuk menghapus demokrasi dalam mekanisme non-yuridis seperti kudeta militer atau keadaan darurat. Generasi sekarang menghancurkan demokrasi dengan jalan mekanisme konstitusional, ikut dalam kontestasi pemilihan kemudian merusak demokrasi dengan langkahlangkah hukum yang diatur dalam konstitusi. ${ }^{12}$ Sehingga menimbulkan efek yang sama dengan authoritarian reversion (kembalinya otoriterianisme).

Pan Mohammad Faiz, “Memaknai Salus populi..., Op.Cit., hlm. 68.

${ }^{8}$ Ibid.

9 J.Gurmann and S. Voigt, "Militan Constitutionalism- A promising Concept to make Constitutional Backsliding less likely?, Econstor”, No. 25, 2019, hlm. 2.

${ }^{10}$ Ibid.

${ }^{11}$ Ibid.

12 A. Satrio, "Constitutional Retrogression in...", Loc. Cit. 
Huq dan Ginburg13 menjelaskan bahwa istilah Constitutional Retrogression adalah istilah yang paling pas untuk menjelaskan rusaknya instrumen demokrasi melalui mekanisme konstitutional. Kekuasaan menjadi terpusat, lepas atau kebal dari pengawasan. Tanda kerusakan disebut oleh Huq dan Ginsburg beriringan dengan terjadinya degradasi tiga prinsip dasar demokrasi, yaitu: pemilihan yang kompetitif, kebebasan berpendapat dan berkumpul, dan kualitas hukum. Hilangnya prinsip-prinsip tersebut menyebabkan lemahnya mekanisme pengawasan atau checks and balances antar lembaga negara atau antar cabang kekuasaan.

Gina Misiroglu yang dikutip oleh Saldi Isra menyatakan bahwa sistem pemerintahan adalah apabila lembaga pemerintah dilihat dari hubungan antara legislatif dan eksekutif. ${ }^{14}$ Hubungan antara Dewan Perwakilan Rakyat (DPR) dan Presiden di Indonesia dalam hal ini terdapat dalam beberapa bidang, yakni bidang legislasi, anggaran, dan pengawasan. Dalam konteks bidang pengawasan dilakukan terhadap jalannya pemerintahan, pemberian keputusan dan persetujuan terhadap agenda kenegaraan, pemberian pertimbangan pada agenda kenegaraan, serta dalam pengisian dan pemilihan dalam beberapa jabatan strategis kenegaraan oleh DPR terhadap Presiden. ${ }^{15}$ Sehingga Presiden dan DPR adalah dua lembaga strategis sebagai arah penentu kebijakan.

Jamak dipahami perkembangan sistem presidensial lebih banyak ditandai dengan masalah dasar mengenai pengelolaan hubungan antara Presiden (eksekutif) dengan lembaga legislatif. Hal itu karena antara Presiden selaku lembaga eksekutif dan DPR selaku lembaga legislatif sama-sama mendapat mandat langsung dari rakyat. Sistem presidensial acap-kali terjebak dalam ketegangan antara eksekutif dengan legislatif. Hal tersebut sering terjadi jika kekuatan partai politik mayoritas di lembaga legislatif berbeda dengan partai politik Presiden. ${ }^{16}$

Di sisi lain, jika partai politik mayoritas di lembaga legislatif sama dengan partai politik pendukung presiden atau mayoritas partai politik di lembaga

13 A. Huq and Tom Gisnburg, "How to lose Constitutional Democracy", UCLA, Rev. 78, 2018, hlm.118 403-404.

${ }^{14}$ Saldi Isra, "Hubungan antara DPR dan Presiden", Jurnal Konstitusi Vol. 10, No. 3, September 2013, hlm.

15 Hezky Fernando Pitoy, "Mekanisme Checks and Balances antara Presiden dan DPR dalam sistem pemerintahan Presidensial di Indonesia”, Lex et Societatis Vol. II, No. 5, Juni 2014, hlm. 5.

${ }^{16}$ Saldi Isra, "Hubungan antara DPR..., Loc. Cit. 
legislatif mendukung presiden, maka praktik sistem presidensial mudah terperangkap menjadi pemerintahan otoriter. Terkait dengan isu itu, Arend Lijphart menegaskan: Majoritarianism means concentration of political power in the hand of majoritym and if the presidency is the respository of this power, it means a powerful president; in other words, the logic of presidentialism is that implies very strong, perhaps even overbearing, president. ${ }^{17}$

Presidensialisme berhadapan pada dua pendulum, antara ketidakseimbangan pemerintahan atau acapkali terjebak dalam otoritarianisme. Konfigurasi politik menentukan arah pemerintahan tersebut bersifat otoriter atau tidak. Disebut otoriter atau tidaknya sebuah pemerintahan dinilai dalam berjalan atau tidaknya mekanisme checks and balances. Berjalanya checks and balances ditinjau salah satunya dari produk hukum yang dihasilkan dari hubungan Presiden dan DPR; apakah benar menjadi sebuah efektifitas pemerintahan atau mencederai nilai-nilai demokrasi yang menjadi sebab kemunduran konstitusi.

Pasal 20A ayat (1) UUD 1945 mengakomodasi secara rinci bahwa DPR memiliki kekuasaan legislasi, kekuasaan penentuan anggaran (budgeting) dan kekuasaan pengawasan (control) untuk menghadirkan checks and balances. Pasal 20A ayat (2) UUD 1945 bahkan menentukan DPR memiliki hak interpelasi, hak angket dan hak menyatakan pendapat.

Sayangnya kewenangan DPR dalam menjalankan fungsi kontrol terhadap Presiden satu dekade terakhir seolah tidak berjalan. Sebagai prototipe ketidakhadiran kontrol tersebut ialah lahirnya Perppu No. 1 Tahun 2017 tentang Organisasi Kemasyarakatan yang telah sah menjadi UU. Secara subtansi UU tersebut dinilai mengesampingkan proses hukum untuk menindak organisasi yang dinilai bertentangan dengan haluan negara. Hal ini bisa membahayakan pilar demokrasi yakni kebebasan berbicara dan berkumpul. Sama halnya dengan Perppu No. 1 Tahun 2020 yang mengatur penanggulangan ekonomi di tengah wabah Covid-19 yang telah sah menjadi UU. Salah satu persoalan yang muncul ialah adanya hak imunitas pejabat tertentu untuk terlepas dari tuntutan perdata dan pidana yang mana bisa membahayakan terhadap ketangguhan hukum. 
Ketidakhadiran fungsi saling mengimbangi Presiden dan DPR sebagai pemegang kuasa legislasi membahayakan pilar demokrasi yang secara tidak langsung berarti mencederai nilai-nilai konstitusi itu sendiri. Maka, untuk sampai pada kesimpulan yang lebih tepat, dan dalam rangka melengkapi kajian hukum tata negara dalam konteks penerapan teori constitutional retrogression untuk menguji indikasi-indikasi di atas, maka artikel ini bermaksud mengkaji hubungan Presiden dan DPR dalm fungsi legislasi pasca amendemen UUD 1945 dengan perspektif teori constitutional retrogression.

\section{Rumusan Masalah}

Rumusan masalah yang akan dikaji dalam artikel ini adalah: pertama, bagaimana hubungan Presiden dan DPR dalam fungsi legislasi pasca amendemen UUD 1945 jika ditinjau dengan perspektif constitutional retrogression? Kedua, bagaimana upaya untuk mencegah terjadinya constitutional retrgoression pada aspek ketangguhan hukum dalam hubungan antara Presiden dan DPR di Indonesia?

\section{Tujuan Penelitian}

Penelitian ini bertujuan untuk menilai hubungan Presiden dan DPR dalam menjalankan fungsi legislasi pasca amendemen UUD 1945 berdasarkan perspektif constitutional retrogession. Penelitian ini juga bertujuan untuk merumuskan upaya untuk mencegah terjadinya constitutional retrogession dalam konteks hubungan antara Presiden dan DPR di Indonesia.

\section{Metode Penelitian}

Metode penelitian yang digunakan dalam penelitian ini adalah yuridisnormatif. ${ }^{18}$ Penelitian ini menggunakan pendekatan perundang-undangan dan konseptual. ${ }^{19}$ Data yang digunakan adalah data sekunder. Bahan hukum yang digunakan dalam penelitian ini adalah bahan hukum primer berupa hukum tertulis yang mengikat, yaitu UUD NRI 1945, serta peraturan perundangundangan yang terkait dengan penelitian ini; bahan hukum sekunder berupa

18 Suteki dan Galang Taufani, Metodologi Penelitian Hukum, PT RajaGrafindo, Depok, 2018, hlm. 175.

19 Yakni pendekatan yang mempelajari adanya konsistensi dan kesesuaian antara suatu undang-undang dengan undang-undang dasar. 
risalah undang-undang, buku, jurnal, artikel dan bahan hukum tersier berupa kamus-kamus. ${ }^{20}$ Data yang terkumpul kemudian dianalisis secara kualitatif, untuk memperoleh kesimpulan sesuai dengan fokus permasalahan penelitian.

\section{Hasil Penelitian dan Pembahasan}

\section{Hubungan Presiden dan DPR dalam Fungsi Legislasi Pasca Amendemen UUD 1945 ditinjau dengan Perspektif Constitutional Retrogression}

Beberapa terminologi mencoba menjelaskan fenomena penurunan kualitas demokrasi (di banyak negara) saat ini, misalanya Abusive Constitutionalism, Autocratic Legalism dan Constitutional Retrogression. Terminologi Abusive Constitusionalism dikembangkan oleh David Landau yang hanya terfokus pada rusaknya demokrasi dengan menggunakan perubahan pada konstitusi atau amendemen, seperti yang terjadi di Venezuela dan Colombia. ${ }^{21}$ Demokrasi justeru bisa saja rusak tanpa menggunakan prosedur perubahan konstitusi seperti yang terjadi di Polandia. ${ }^{22}$

Penelitian ini menggunakan terminologi Constitutional Retrogression, yang oleh Ginsburg dan Huq ditentukan 3 indikator untuk mengukur ada tidaknya penurunan pada pemerintahan demokratis, yakni: (1) pemilihan umum yang demokratis; (2) kebebasan berbicara dan berkumpul; (3) ketangguhan hukum dan institusi hukum. ${ }^{23}$

Ginsburg dan Huq menjelaskan ancaman saat ini bukan adanya Authoritarian Reversion yang ditandai dengan rusaknya tatanan demokrasi melalui perebutan kekuasaan secara paksa, misalnya kudeta militer atau keadaan darurat, melainkan Constitutional Retrogression yang melibatkan rusaknya demokrasi dengan melubangi hukum dari dalam. ${ }^{24}$ Kerusakannya tidak akan secara langsung, namun secara perlahan dan berangsur mengikis tiga elemen penting dalam demokrasi di suatu negara. Constitutional Retrogression juga memiliki efek

\footnotetext{
${ }^{20}$ Soerjono Soekanto, Pengantar Penelitian Hukum, UI Press, Jakarta, 1986, hlm. 51.

21 A. Satrio, "Constitutional Retrogression in..., Op. Cit., hlm. 275

22 Ibid.

${ }^{23}$ Ibid.

${ }^{24}$ A. Huq and Tom Gisnburg, Op. Cit., hlm. 123-136.
} 
yang sama dengan kembalinya otoritarianisme. Ginsburg dan Huq menyebut bahwa kemunduran tersebut terjadi dalam 5 tanda, yaitu: ${ }^{25}$

1. Amendemen Formal; misalnya memarjinalkan oposisi dan menghapus masa jabatan presiden.

2. Reduksi atau penghapusan lembaga pengawas.

3. Sentralisasi kekuasaan kepada eksekutif.

4. Melemahkan ruang publik semisal dibentuknya undang-undang yang memungkinkan pemerintah dengan mudah membungkam/membubarkan media, organisasi non-pemerintah atau organisasi masyarakat.

5. Mengikis kompetisi politik, semisal melemahkan ruang aksi bagi oposisi dengan memanipulasi aturan pemilihan (sehingga sulit ikut bersaing).

Fenomena kerusakan demokrasi ini berkaitan erat dengan bangkitnya kaum populis ${ }^{26}$ yang tercatat dalam 20 tahun terakhir, seperti Presiden Alberto Fujimori di Peru (1995), Hugo Chavez di Venezuela (1999), Rafael Correa di Ekuador (2008), Evo Morales di Bolivia (2009) Viktor Orban di Hungaria (2011) dan Presiden Erdogan di Turki. ${ }^{27}$ Bangkitnya kaum populis ini mengatasnamakan mandat dari rakyat dan menyatakan 'lawan' terhadap kelompok yang mereka sebut sebagai kaum elit korup. Kaum populis ini mengatasnamakan dan mengklaim sebagai pemilik legitimasi tertinggi dari rakyat, yang mencoba mereformasi struktur ekonomi dan politik. Kaum yang disebut kelompok populis sebagai elit korup saat menduduki kekuasaan dinilai tidak boleh memiliki ruang untuk berkompetisi atau ruang geraknya dipersempit. ${ }^{28}$

Perasaan itulah yang menyebabkan kaum populis berbahaya bagi demokrasi. Kaum populis mengkritik dan anti dengan sistem yang dulu sehingga kekuasaan dipergunakan untuk mengubah hukum dan agenda politiknya. Para pemimpin populis juga cenderung mengonsolidasikan kekuasaannya. Memperkuat cabang eksekutif dan menghilangkan masa jabatan. Kaum populis juga menyerang lembaga independen yang berfungsi memeriksa kekuasaan, seperti pengadilan, media, otoritas pajak dan komisi pemilihan. Pemimpin

25 Ibid.

${ }^{26}$ Populis atau Populisme ialah sebuah ideologi yang membenturkan antara kaum yang mengatasnamakan rakyat dengan kaum yang disebut sebagai elit korup. Ideologi tersebut bermaksud untuk memobilisasi masa melakukan perlawanan terhadap yang mereka sebut sebagai musuh bersama; biasanya elit partai, pemerintahan korup. Lihat, Mudde, C. \& Kaltwasser, C. R, Populism: A Very Short Introduction, Oxford University Press, New York, 2017, hlm. 42-43.

${ }^{27}$ Landau sebagaimana dikutip oleh A. Satrio, "Constitutional Retrogression in..., Op. Cit., hlm. 277.

28 A. Satrio, "Constitutional Retrogression in..., Op. Cit., hlm. 277. 
populis mengisi lembaga-lembaga ini dengan loyalis partai sehingga tidak lagi independen. Sasaran utama mereka biasanya mahkamah konstitusi, karena di negara yang telah mengalami masa transisi dari otoritarianisme ke demokrasi, mahkamah konstitusi memiliki fungsi utama menjaga demokrasi dengan melindungi independensinya, lembaga negara lain dan menegakkan hak asasi manusia.

Frekuensi penurunan kualitas demokrasi sejak 1970-an menggunakan kategorisasi freedom house menunjukkan sekitar 2010 kurva rezim hybrid 29 dan autokrasi mengalami kenaikan sedangkan kualitas demokrasi menunjukan penurunan. Berbeda dengan kembalinya otoritarianisme, kemunduran terjadi karena pertama, terjadi secara perlahan-lahan; kedua, melibatkan mekanisme yang berbeda; ketiga, titik akhirnya adalah quasi-otoritarianisme atau otoriter semu..$^{30}$

Pasca amendemen UUD 1945 hubungan kelembagaan bukan lagi bersifat vertikal namun bergeser menjadi horizontal. Tidak ada lagi sebutan lembaga tertinggi negara yang pada mulanya dipegang oleh Majelis Permusyawaratan Rakyat (MPR). ${ }^{31}$ Dengan maksud melaksanakan sistem pemisahan kekuasaan (Separation of Power) maka reformasi mencoba mengaktifkan fungsi pemerintahan yang sejajar namun tetap saling mengawasi dan mengimbangi. Posisi Presiden dan DPR sama kuat sebagaimana tergambar dalam Pasal 7C UUD 1945 bahwa "Presiden tidak dapat membekukan dan/atau membubarkan Dewan Perwakilan Rakyat".

Tantangan yang paling mendasar dalam ketatanegaraan Indonesia yang menganut sistem presidensial ialah mengenai cara mengatur hubungan antatara Presiden dan DPR. ${ }^{32}$ Selama empat kali perubahan UUD 1945 (1999-2002) purifikasi sistem presidensial itu dilakukan dalam bentuk: (1) mengubah proses pemilihan Presiden dan Wakil Presiden dari pemilihan dengan sistem perwakilan (pemilihan di MPR) menjadi pemilihan secara langsung; (2) membatasi periodisasi masa jabatan Presiden/Wakil Presiden; (3) memperjelas tata-cara

29 Disebut juga demokrasi semu, demokrasi separuh, demokrasi berintensitas rendah, ialah sistem pemerintahan yang tetap melaksanakan pemilu, tetapi mengekang kebebasan sipil sehingga warga tidak mengetahui aktivitas pemegang kekuasaan yang sesungguhnya.

${ }^{30}$ A. Huq and Tom Gisnburg, Op. Cit., hlm. 97.

31 Jimly Asshiddiqie, Perkembangan dan Konsolidasi Lembaga Negara Pasca Reformasi, Sinar Grafika, Cet. 2, Jakarta Timur, 2012, hlm. 116.

32 Saldi Isra, Op. Cit., hlm. 404. 
pemakzulan Presiden/Wakil Presiden; serta (4) menata ulang lembaga perwakilan rakyat. 3 dari 4 purifikasi tersebut terkait langsung dengan hubungan antara Presiden dan DPR. ${ }^{33}$

Hubungan Presiden dan DPR terjadi dalam menjalankan fungsi legislasi misalnya. Idealnya dalam sistem presidensial memiliki ciri sebagai berikut: ${ }^{34}$

1. Proses awal persiapan rancangan undang-undang, eksekutif dan (anggota) legislatif punya kesempatan yang sama untuk mengajukan rancangan undang-undang.

2. Semua rancangan undang-undang dibahas dan disetujui lembaga legislatif.

3. Karena pembahasan dan persetujuan menjadi wewenang eksklusif lembaga legislatif, pemegang kekuasaan eksekutif dapat mengajukan keberatan atau menolak (dalam bentuk veto) rancangan undang-undang yang disetujui legislatif.

4. Sesuai dengan prinsip supremacy of legislative power, pembentukan undangundang dalam sistem presidensial, keberatan atau penolakan eksekutif dapat ditolak kembali oleh legislatif (veto Override).

5. Terkait dengan penolakan lembaga legislatif atas veto presiden, rancangan diumumkan dan dinyatakan berlaku menjadi undang-undang.

Sistem presidensial di Indonesia dalam praktiknya tidak bisa terlepas atau mengandung unsur sistem parlementer. Berdasarkan Pasal 20A ayat (2) UUD NRI 1945, DPR dalam menjalankan fungsi legislasi memiliki hak angket dan hak interpelasi (yang menjadi ciri sistem parlementer). Memang sulit menemukan sistem yang terbebas dari pengaruh sistem lain, sehingga semua itu menjadi semakin rumit karena sebagian anggota DPR sering menampakkan diri sebagai wakil partai politik daripada sebagai wakil rakyat.

Perubahan konstruksi presidensialisme dalam UUD 1945 secara signifikan pada perubahan pertama, kemudian penguatan kelembagaan DPR pada perubahan kedua, yang justeru bukannya melahirkan keseimbangan kekuasaan antara Presiden dan DPR, namun menimbulkan ketidakjelasan sistem presidensial yang ingin dibangun melalui perubahan UUD 1945. Pola relasi kekuasaan Presiden dan pemberdayaan DPR, di satu sisi, dengan upaya mempertahankan sistem presidensial, di sisi lain memungkinkan terjadinya

\footnotetext{
33 Ibid., hlm. 405.

${ }^{34}$ Ibid., hlm. 407.
} 
ketegangan di parlemen dengan berbagai macam interpelasi dan penolakan DPR. Hal ini memungkinkan terjadinya deadlock antara Presiden dan DPR. ${ }^{35}$

DPR mempunyai dua supremasi kewenangan terhadap Presiden, yaitu keharusan pelaksanaan sejumlah agenda kenegaraan yang memerlukan "pertetujuan" dan "pertimbangan" DPR. Persetujuan DPR diperlukan oleh Presiden dalam beberapa hal berikut:

a. Menyatakan perang, membuat perdamaian, dan perjanjian dengan negara lain.

b. Setelah presiden menerbitkan peraturan pemerintah pengganti undang-undang.

c. Anggota Komisi Yudisial diangkat diangkat dan diberhentikan Presiden dengan persetujuan DPR;

Sementara itu, pertimbangan DPR diperlukan dalam beberapa hal berikut:

a. Mengangkat duta;

b. Menerima penempatan duta negara lain;

c. Memberi amnesti dan abolisi.

Persetujuan dan pertimbangan DPR masih muncul dalam proses pengisian jabatan-jabatan strategis yang diatur di level undang-undang. Misalnya, pengisian jabatan Kepala Polisi RI, sebagai user, Presiden tidak bisa mandiri memilih dan menentukan Kapolri. Pasal 11 UU Nomor 2 Tahun 2002 tentang Kepolisian Negara RI menyatakan bahwa: (1) Kapolri diangkat dan diberhentikan Presiden dengan persetujuan DPR (2); usul pengangkatan dan pemberhentian Kapolri diajukan oleh Presiden kepada DPR disertai dengan alasannya. Pola yang tidak jauh berbeda dapat pula ditemukan dalam pengisian Panglima TNI.

Hak konfirmasi kepada Senat dalam praktik sistem presidensial di Amerika Serikat adalah sesuatu yang biasa. Meskipun demikian, anggota Senat dan Senat sendiri paham betul bahwa kekuasaannya sangat terbatas yaitu hanya memberi konfirmasi nama yang diusulkan Presiden. Perbedaan secara tegas kewenangan Presiden dan Senat dalam pengisian jabatan publik itu sekaligus menjadi jembatan mengenai bagaimana mekanisme checks and balances dibangun dalam praktik penyelengaraan negara. ${ }^{36}$

35 A. Salman Magalatung, Desain Kelembagaan Negara Pasca Amandemen UUD 1945, Gramata Publishing, Bekasi, 2016, hlm. 166.

36 Ibid., hlm. 410. 
Perkembangan terkini proses pengisian jabatan untuk semua lembaga independen di Indonesia tidak ada yang tidak bersentuhan dengan DPR. Secara teoritis pola demikian menjadi bangunan pelaksanaan mekanisme checks and balance antara DPR dan Presiden dalam pengisian lembaga negara independen. Nama-nama hasil seleksi pemerintah bahkan dilanjutkan dengan mekanisme fit and proper test di DPR. Persoalannya bukan adanya mekanisme fit and proper test, tetapi lebih kepada kecenderungaan DPR masuk ke wilayah kewenangan Presiden.

DPR memegang kekuasaan membentuk undang-undang, tetapi tidak melakukannya sendiri, melainkan bersama dengan Presiden. ${ }^{37}$ Pembentukan undang-undang dan pelaksanaannya, tidak muncul checks and balances, melainkan dalam hal DPR dan Presiden telah menyetujui rancangan undang-undang, kemudian Presiden tidak mengesahkannya, dalam kurun waktu tiga puluh hari semenjak rancangan undang-undang itu disetujui, maka rancangan undangundang tersebut tetap sah menjadi undang-undang dan wajib diundangkan. Pihak yang wajib mengundangkan bukan presiden, melainkan pembantunya yang berkedudukan sebagai menteri. ${ }^{38}$

Begitupun dalam fungsi anggaran, anggaran pendapatan dan belanja negara ditetapkan setiap tahun dengan undang-undang. Ini berarti bahwa rancangan undang-undang tentang Anggaran Pendapatan dan Belanja Negara (APBN) yang diajukan oleh Presiden dibahas bersama dengan DPR dengan memerhatikan pertimbangan DPD. Apabila DPR tidak menyetujui rancangan anggaran yang diusulkan, maka pemerintah menjalankan anggaran pendapatan dan belanja negara tahun lalu. Solusi berkaitan dengan hal tersebut sudah diatur dalam Undang-Undang Dasar. ${ }^{39}$

Hak interpelasi, hak angket, dan hak menyatakan pendapat secara konstitusional dijamin dalam UUD. Meskipun demikian, pelaksanaan hak tersebut ditentukan oleh berbagai kepentingan politik fraksi-fraksi yang ada di DPR. Dapat saja terjadi hak angket disepakati oleh sejumlah fraksi dalam DPR,

${ }^{37}$ Sri Soemantri, Hukum Tata Negara Indonesia, Cetakan kedua, Remaja Rosdakarya, Bandung, 2015, hlm. 212-213.

${ }^{38}$ Ibid.

${ }^{39}$ Lihat Pasal 23 ayat (3) UUD NRI 1945. 
tetapi ketika dilakukan pemungutan suara, tidak mendapat dukungan dari mayoritas anggota yang ada dalam DPR. Padahal, kemungkinan sekali hak angket tersebut akan dilakukan terhadap kebijakan pemerintah yang penting dan strategis serta berdampak luas pada kehidupan bermasyarakat dan bernegara yang diduga bertentangan dengan peraturan perundang-undangan. Hal tersebut juga berlaku terhadap hak interpelasi dan hak menyatakan pendapat.

Kuatnya kewenangan DPR pasca amendemen UUD 1945 menjadikannya sebagai lembaga paling strategis dengan kewenanganya yang luas dan didukung pula dengan imunitasnya yang kuat. De Lolme menyindir lembaga parlemen dengan sebuah kiasan "bahwa parlemen (lembaga legislatif) dapat melakukan apapun kecuali mengubah laki-laki menjadi perempuan, dan perempuan menjadi laki-laki". ${ }^{0} \mathrm{Di}$ dalam sistem presidensial, siapapun yang menjadi Presiden harus mempunyai dukungan yang kuat di DPR demi keberlangsungan sistem pemerintahan. Namun di sisi lain kedudukan oposisi di DPR pun sangat dibutuhkan untuk terciptanya keseimbangan.

Sejak Joko Widodo (Jokowi) menjabat Presiden pada tahun 2014, ia menjadi Presiden dengan dukungan yang lemah karena 67\% suara di DPR dikuasai oleh partai oposisi yang menjadi pendukung kompetitornya pada pilpres yakni Prabowo Subianto. Namun, ia berhasil mengonsolidasikan kekuatan dengan berhasil membuat dua partai besar (Golkar dan PPP) dari oposisi beralih berada di pihak pemerintah. ${ }^{41}$

Salah satu langkah Presiden dan DPR era Pemerintahan Jokowi yang sempat terjadi pro-kontra ialah lahir dan disahkannya Perppu Nomor 2 Tahun 2017 tentang Perubahan Atas Undang-Undang Nomor 17 Tahun 2013 tentang Organisasi Kemasyarakatan. Pada intinya pemerintah berwenang untuk membubarkan ormas yang dianggap berbahaya bagi keutuhan negara tanpa melalui proses peradilan. ${ }^{42}$ Ketentuan itu tentunya mencederai salah satu pilar demokrasi yaitu kebebasan berbicara dan berkumpul sekaligus mencederai due process of law. Sistem ini tentu tidak dapat memicu kesewenang-wenangan bagi siapapun yang menjadi penguasa,

40 A.V. Dicey, Pengantar Studi Hukum Konstitusi, Cetakan kelima, Nusamedia, Bandung, 2015, hlm. 134.

41 A. Satrio, Op. Cit., hlm. 279.

42 Lihat Pasal 61 ayat (3) huruf a dan b UU No. 16 Tahun 2017 tentang Perppu Nomor 2 Tahun 2017 tentang Perubahan atas Undang-Undang Nomor 17 Tahun 2013 tentang Organisasi Kemasyarakatan. 
karena dengan kewenangan subjektifnya dapat sewenang-wenang membubarkan Ormas. Sistem pembubaran ormas semacam ini menandakan kemunduran konstitusi.

Sama halnya dengan lahirnya Perppu No. 1 Tahun 2020 tentang Kebijakan Keuangan Negara dan Stabilitas Sistem Keuangan untuk Penanganan Pandemi Corona Virus Disease 2019 (Covid-19) dan/atau dalam Rangka Menghadapi Ancaman yang Membahayakan Perekonomian Nasional dan/atau Stabilitas Sistem Keuangan. Kuatnya koalisi pemerintah di DPR pasca pemilu 2019 memperkuat hubungan keduanya. Banyak ahli mengkritisi Perppu yang mencederai aspek-aspek penting dalam prinsip negara hukum.

Para ahli menilai masih banyak kecacatan adanya kewenangan Presiden mengubah APBN dengan alasan adanya pandemi Covid-19.43 Imunitas hukum pemerintah berpotensi menimbulkan tindak pidana korupsi dan penyalahgunaan anggaran, sehingga dapat mencederai asas equality before law dan due process of law. Perppu tersebut juga melanggar prinsip negara hukum yang transparan, terbuka dan bertanggung jawab, bertentangan pula dengan komitmen pemberantasan korupsi karena pemberian kewenangan yang absolut kepada sejumlah pejabat yang disebut dalam perppu. ${ }^{44}$

Perppu tersebut disahkan dalam sidang paripurna DPR oleh mayoritas fraksi, dan hanya fraksi Partai Keadilan Sejahtera (PKS) saja yang menolak. ${ }^{45}$ Jika kedekatan ini semakin berlanjut dapat mengkhawatirkan bahwa konstitusi menjadi alat politik kekuasaan jangka pendek, DPR hanya menjadi rubber stamps (istilah bagi lembaga legislatif yang menuruti kemauan atau kebijakan pemerintah) atas kebijakan lembaga kepresidenan, sehingga hanya menjadi bayang-bayang lembaga kepresidenan. DPR menjadi abai atas negasi, derogasi,

\footnotetext{
${ }^{43}$ Teguh Firmansyah, Ganti Perppu 1/2020 dengan UU APBN Perubahan, https://m.republika.co.id/berita/q8xx78377/syarief-hasan-ganti-perppu-12020-dengan-uu-apbn-perubahan, (diakses pada tanggal 5 Juli 2020 pukul 11. 29 wib).

${ }^{44}$ Andi Sarputra, Khawatirnya pakar bukum bingga Anggota DPR terhadap Perppu Corona, https://news.detik.com/berita/d-4991570/khawatirnya-pakar-hukum-hingga-anggota-dpr-terhadap-perppucorona/4, (diakses pada tanggal 5 Juli 2020 pukul 11. 09 wib).

45 Fitria Chusna Farisa, Perppu 1/2020 Terbit dan Disabkan dalam Satu Kali Masa Sidang DPR, Pemohon Nilai Bertentangan dengan UUD, https://nasional.kompas.com/read/2020/05/20/13435901/perppu-1-2020-terbit-dandisahkan-dalam-satu-kali-masa-sidang-dpr-pemohon?page=all, (Diakses pada tanggal 5 Juli 2020 Pukul 11.52).
} 
degradasi kekuasaannya oleh lembaga kepresidenan, sehingga kekuasaan Presiden menjadi lebih dominan, monopolistik, superior dan kebal hukum.

AV Dicey mengingatkan dalam pengertian Rule of Law bahwa:46

a. Supremasi hukum, tidak boleh ada kesewenang-wenangan, seseorang hanya boleh dihukum bila melanggar hukum;

b. Kedudukan yang sama di depan hukum baik bagi rakyat maupun pejabat;

c. Terjaminnya hak-hak asasi manusia oleh undang-undang dan keputusankeputusan pengadilan.

Subtansi beberapa Perppu yang dinilai bermasalah dan berpotensi melanggar unsur wajib dalam rule of law, sedangkan tetap mendapat persetujuan DPR justru menimbulkan kecurigaan bahwa label DPR hanya menjadi 'tukang cap' kebijakan pemerintah semakin terlihat. Meskipun ada pola yang ideal untuk menjaga hubungan Presiden dan DPR tidak jauh namun juga tidak terlalu berdekatan, semua berjalan menjaga nilai dalam konstitusi dan mengedepankan kepentingan rakyat.

Kedekatan Presiden dan DPR bukan hanya berhasil memuluskan rancangan undang-undang yang diusulkan Presiden; sebaliknya, rancangan undang-undang yang diusulkan oleh DPR pun mudah sekali disetujui Presiden. Salah satunya disahkannya RUU Mineral dan Batu Bara menjadi Undang-Undang. Persoalan muncul misalnya dalam Pasal 4 ayat (2) bahwa penguasaan mineral dan batu bara menjadi kewenangan pemerintah pusat, hal tersebut bertentangan dengan semangat desentralisasi kekuasaan. Pasal 42 dan 42A yang semula eksplorasi pertambangan hanya dibatasi untuk 2 tahun namun dalam pasal baru tersebut diperbolehkan hingga 8 tahun. Dan beberapa pasal lainnya ${ }^{47}$ yang dinilai bukan untuk kepentingan rakyat namun cenderung menguntungkan pengusahapengusaha besar.

Contoh lain produk hukum Presiden dan DPR yang tidak lepas dari persoalan ialah Omnibus Law Cipta Kerja, sejak diserahkan oleh Presiden untuk dibahas di DPR bahkan setelah disepakati untuk diserahkan kepada Presiden

\footnotetext{
${ }^{46}$ Hariyono dkk, Membangun Negara Hukum yang Bermartabat, Setara Press, Malang, 2013, hlm. 258-259.

${ }^{47}$ Pasal 169A, Dihapusnya Pasal 165 UU Minerba Lama, Pasal 162 dan 164.
} 
kembali, draf acapkali berubah-ubah halaman. ${ }^{48}$ Banyaknya kesalahan ketik dan segudang polemik yang krusial disetujui dalam waktu yang relatif singkat. Bahkan sekalipun pernah disebut sebagai salah ketik dalam Pasal 170 ayat (1, 2 dan 3) terdapat ketentuan bahwa pemerintah dapat mengubah undang-undang dengan peraturan pemerintah. Jika disetujui tanpa pengawasan dan kontrol maka ini berbahaya untuk penyelenggaraan ketatanegaraan karena menyalahi asas Lex Superior. Menggeser fungsi legislasi yang menjadi kewenangan DPR menjadi kewenangan Presiden.

Jika terjadi kontroversi dalam subtansi legislasi, sebagai warga negara memiliki hak untuk mengajukan keberatan ke lembaga yudikatif dalam hal ini Mahkamah Konstitusi (MK). MK juga memiliki kewenangan judicialization of politics; dimana Ran Hirschl menyebut yudisialisasi politik adalah "... the everaccelerating reliance on courts and judicial means for addressing core moral predicaments, public policy questions, and political controversies" ${ }^{49}$

Lembaga peradilan tidak hanya menangani perkara penyelesaian pihak yang bersengketa. Dengan dibekali kewenangan untuk menguji suatu kebijakan, lembaga peradilan terlibat dalam pengubahan kebijakan yang selama ini menjadi urusan pemerintahan dan lembaga perwakilan. 50 Namun peluang MK dalam menguji produk hukum Presiden dan melibatkan DPR (Perppu) tidak lepas dari persoalan. Persoalannya antar lain mengenai akibat hukum yang ditimbulkan, potensi menyalahi konstitusi karena telah masuk ke ranah kewenangan eksekutif dan legislatif. Apalagi kewenangan MK menguji Perppu berpijak pada interpretasi hakim (judicial interpretation) ${ }^{51}$ terhadap UUD 1945. Akibat hukum pengujian materiil perppu oleh karenanya dinilai masih dilematik.

Apalagi saat ini MK cenderung di desain tidak imparsial. Revisi UU MK yang telah disahkan pada awal september 2020 telah mengubah ketentuan masa

48 Bisma Septalisma, 5 Versi Draf Omnibus Law Ciptaker Usai Disahkan DPR https://www.cnnindonesia.com/nasional/20201013091525-32-557717/5-versi-draf-omnibus-law-ciptaker-usaidisahkan-dpr (diakses pada tanggal 19 November 2020 pukul 16.59 WIB)

${ }^{49}$ Ran Hirschl, "The Judicialization of Mega-Politics and the Rise of Political Courts", The Annual Review of Political Science, Vol. 11, hlm. 94.

${ }^{50}$ Bisariyadi, Yudisialisasi Politik dan Sikap Menahan Diri: Peran Mahkamah Konstitusi dalam Menguji Undang-Undang, Jurnal Konstitusi, Vol. 12 No. 3, September 2015, hlm. 478-479.

51 Ali Marwan, "Pengujian Peraturan Pemerintah Pengganti Undang-Undang (The Review Of The Government Regulation In Lieu Of Law)”, Jurnal Legislasi Indonesia Vol 13 No 2, Juni, 2016, hlm. 150. 
jabatan hakim MK yang mulanya 5 tahun dan dapat dipilih kembali pada periode berikutnya menjadi maksimal usia 70 tahun atau 15 tahun sejak diangkat menjadi hakim. ${ }^{52}$ Formasi hakim MK dengan konfigurasi politik yang sama dalam Presiden dan DPR riskan bagi lembaga yudikatif dalam hal ini MK tidak lagi bertindak secara imparsial.

Produk-produk hukum yang sarat akan berbagai masalah di atas menjadi bukti bahwa fungsi checks and balances DPR terhadap Presiden tidak berjalan. Sehingga Indonesia dalam satu dekade terakhir mengalami constitutional retrogression dengan menurunnya salah satu unsur penting demokrasi yakni kualitas hukum dan institusi hukum.

\section{Upaya untuk Mencegah Constitutional Retrgoression pada Aspek Ketangguhan Hukum dalam Hubungan antara Presiden dan DPR di Indonesia}

Mengacu kepada persoalan yang telah diuraikan di atas, dapat tergambar bahwa secara perlahan Indonesia mengalami tanda-tanda constitutional retrogression. Konstitusi mengamanatkan hubungan yang sinergis antar lembaga untuk saling mengimbangi, namun dalam pelaksanaannya fungsi tersebut seolah tak berjalan. Terbukti menurunnya kualitas hukum dan ketangguhan institusi hukum.

Penulis menemukan dua faktor hubungan Presiden dan DPR menimbulkan kemunduran konstitusi; yakni faktor hukum dan dan faktor politik kepentingan. Faktor hukum didukung dengan besarnya angka Presidential Treshold (PT) ${ }^{53}$ dalam pemilu serentak, menyebabkan ongkos politik semakin mahal. Tawar menawar jabatan strategis diduduki oleh para pendukung. Jika ada calon yang hendak mengajukan diri menjadi Presiden maka partai akan menjual suara dengan harga yang tidak murah. Sehingga berimbas pada faktor yang kedua yakni politik kepentingan; kucuran dana dari pengusaha-pengusaha yang berkepentingan. Produk hukum yang dihasilkan seringkali menguntungkan pengusaha bukan rakyat secara umum.

\footnotetext{
${ }^{52}$ Lihat Pasal 87 ayat (b) "Hakim konstitusi yang sedang menjabat pada saat Undang-Undang ini diundangkan diangsap memenubi syarat menurut Undang- Undang ini dan mengakbiri masa tugasnya sampai usia 70 (tujuh puluh) tahun selama keseluruban masa tugasnya tidak melebibi 15 (lima belas) tahun."

${ }^{53}$ Pasal 222 UU Pemilu "Pasangan calon diusulkan oleh partai politik atau gabungan partai politik peserta pemilu yang memenubi persyaratan perolehan kursi paling sedikit 20\% (dua puluh persen) dari jumlah kursi DPR atau memperoleh 25\% (dua pulub lima persen) dari suara sah secara nasional pada pemilu anggota DPR sebelumnya."
} 
Ketua Umum PBB Yusril Ihza Mahendra pada November 2020 yang menyambut berdirinya partai MASYUMI, mengatakan "Sepanjang pengalaman saya, tidak ada para cukong dan para pengusaha besar itu yang sudi mendanai Partai Islam. Makanya kebanyakan partai-partai Islam itu hidupnya ngos-ngosan,"54 hal tersebut menandakan bahwa partai memerlukan ongkos politik yang tidak sedikit. Sehingga regulasi tentang PT tersebut mesti dikaji ulang.

PT menjadi hal yang paling fundamental sebagai pijakan awal penentu Quo Vadis pola hubungan Presiden dan DPR akan dibawa. Pasalnya, sekalipun MK dalam putusannya Nomor 51-52-59/PUU-VI/2008 berpendapat bahwa PT ialah open legal policy dan bersifat langkah awal, karena yang menentukan adalah saat pemilihan umum secara langsung, dalam praktiknya justru tidak demikian. Besarnya angka PT berpotensi menimbulkan beberapa hal: (1) politik bagi-bagi kursi Kabinet (menteri) atau transaksional yang bersifat elitis, sentralistis dan tertutup; (2) mengikis hak konstitusional calon lain untuk ikut berkompetisi (inkonstitusional); (3) peluang terjadinya pemerintahan semi-otoriter dan sekaligus memarjinalkan oposisi dalam parlemen;55 (4) dengan ketentuan pemilu dilaksanakan secara serentak Presiden dan DPR, semakin memperkuat posisi partai besar.

Apabila berkaca pada Amerika Serikat, Peru, Mexico, Kolombia, Brazil yang juga menganut sistem presidensial, tetapi tidak menerapkan ambang batas dalam pemilihan presiden demi berlangsungnya pemilihan yang demokratis. ${ }^{56}$ Ketiadaan PT tidak menjamin akan banyaknya calon yang diusung partai sebagaimana yang dikhawatarikan di Indonesia. Meksiko dan Kolombia misalnya, pada pemilu 2012 dan 2014 nama yang mencalonkan diri menjadi presiden hanya empat atau lima nama saja. Sementara jika melihat dari pemilu di Indonesia pada 2004, yang pada saat itu Susilo Bambang Yudhoyono hanya didukung oleh partai-partai kecil, pada kenyataannya rakyat melihat pada sosok

54 Budiarti Utami Putri, "Hormati Masyumi Reborn, Yusril cerita sulitnya partial Islam Cari Dana", https:// nasional.tempo.co/read/1403825/hormati-masyumi-reborn-yusril-cerita-sulitnya-partai-islam-caridana/full?view=ok, (Diakses pada tanggal 21 November 2020 pukul 12.48 WIB).

${ }_{55}$ Robi Ardianto, 7 bahaya presidential threshold, https://www.alinea.id/politik/7-bahaya-presidentialtreshold-b1U3O9cPY, (diakses pada tanggal 07 Juli 2020 Pukul. 16.10 WIB)

56 Abdul Ghofar, "Problematika Presidential Threshold: Putusan Mahkamah Konstitusi dan Pengalaman di Negara Lain”, Jurnal Konstitusi Vol. 15, No. 3, September 2018, hlm. 490-497. 
calon, bukan hanya karena jumlah calon yang sedikit dan dinominasikan oleh banyak partai politik semata. ${ }^{57}$

Ambang batas yang cukup besar saat ini sangat sarat akan hubungan Presiden dan DPR yang 'semakin mesra', sehingga bisa berbahaya bagi konstitusi atau interpretasi konstitusi. Hal ini dikarenakan, perubahan konstitusi disebabkan adanya some primary source yang salah satunya disebabkan adanya desakan kekuatan partai politik parlemen. 58

Kekuatan pendorong perubahan konsitusi dibagi menjadi dua, yaitu; pertama, kekuatan yang dapat menciptakan berubahnya kondisi di suatu negara. Kekuatan itu memang tidak mengubah kalimat-kalimat dalam konstitusi secara eksplisit, namun mampu menciptakan kondisi yang dapat mengubah makna atau kestabilan supremasi konstitusi. Kedua, kekuatan yang mampu menciptakan kondisi sehingga terlaksananya perubahan konstitusi secara formal, melalui interpretasi hakim atau melalui konvensi ataupun kebiasaan ketatanegaraan. ${ }^{59}$

Koalisi gemuk berpeluang memicu anggota parlemen bersepakat melakukan perubahan dalam konstitusi baik perubahan yang tersurat maupun yang tersirat dengan kata lain konstitusi ditafsirkan sesuai kehendak.

Penulis memandang perlu adanya regulasi yang jelas, diantaranya (1) mengecilkan atau menghapus angka PT; (2) Indonesia dengan sistem multipartai (artinya membawa ideologi masing-masing partai) idealnya disandingkan dengan sistem proporsional dengan daftar terbuka.60 Pemilih bukan memilih orang namun memilih partai dengan ideologinya masing-masing. Namun dalam pemilihan tetap menghadirkan nama-nama yang sudah dicalonkan oleh partai untuk duduk di parlemen jika partai tersebut memenuhi syarat. Partai-partai yang tidak selaras dengan keinginan masyarakat oleh karenanya akan tereduksi dengan sendirinya tanpa mencederai hak konstitusionalnya.

57 Ibid., hlm. 497.

${ }^{58}$ I Dewa Gede Atmadja, Suko Wiyono dan Sudarsono, Teori Konstitusi dan konsep Negara Hukum, Setara Press, Malang, 2015, hlm. 61.

${ }^{59}$ Saldi Isra dan Feri Amsari, "Perubahan Konstitusi melalui Tafsir Hakim MK", Jurnal Konstitusi, Vol. 1. No.1, November 2008, hlm. 2.

60 Zainal Abidin Pakpahan, "Pelaksanaan Pemilihan Umum Serentak pada Pemilihan Presiden dan Wakil Presiden, Anggota DPR, DPD dan DPRD sebagai implementasi Pelaksanaan sistem Demokrasi Pancasila", Jurnal Sosial ekonomi dan Humaniora, Vol. 5 No. 2, 2019, hlm. 176. 
Erfandi menyebut bahwa dalam pembatasan partai politik mesti menimbang beberapa alasan subyektif, diantaranya sebagai berikut:

Pertama, pembenahan dari sisi undang-undang; kedua, penyederhanaan partai politik; ketiga, ditinjau dari segi ekonomi, semakin banyak partai yang mencalonkan terutama pencalonan parlemen, beban pemilihan akan semakin besar begitu pula sebaliknya; keempat, mesti meninjau dari segi sosial-politik termasuk di dalamnya, pendidikan politik, iklim politik yang kondusif, menghimpun aspirasi publik, dan partisipasi masyarakat. ${ }^{61}$

Hukum dibentuk untuk mengakomodasi 3 kepentingan, yaitu Individual, public, dan social interest. 62 Idealnya partai digunakan hanya sebatas kendaraan, setelah sampai pada tujuan, maka tak ada lagi kepentingan partai, yang ada ialah amanah rakyat.

Beberapa tanda masalah menurunnya kualitas demokrasi menyebabkan pemerintahan Jokowi dan partai pendukungnya di DPR mirip dengan dampak yang dilakukan oleh kaum populis. ${ }^{63}$ Besarnya angka PT didukung iklim politik yang tidak sehat menyebabkan terjadinya banyak penyalahgunaan kekuasaan. Politik bagi-bagi kursi tidak bisa dihindari sehingga acapkali posisi strategis diisi oleh "loyalis pengusung".64 Mengecilkan atau meniadakan angka PT tidak menjadi jaminan melemahkan sistem presidensial, sebagaimana di beberapa negara yang menganut sistem yang sama tanpa adanya PT tetap berjalan dan saling mengimbangi. Kalaupun terjadi ketegangan antara Presiden dan DPR menurut penulis lebih kepada soal politik bukan pada regulasi.

Apabila soliditas hubungan Presiden dan DPR ini semakin kental maka cabang yudikatif mesti menjadi penengah. MK dalam hal ini sebagai the guardian of constitution ${ }^{65}$ lembaga tertinggi pelindung konstitusi yang seharusnya menjadi penengah. Peran yudikatif dalam hal ini MK mesti menjadi penengah yang adil

${ }^{61}$ Erfandi, Parliamentary Threshold dan HAM dalam Hukum Tata Negara Indonesia, Setara Press, Malang, 2014, hlm. 106-11.

${ }^{62}$ Elise Nalbandian, "Sociological Jurisprudence: Roscoe Pound's Discussion on Legal Interests and Jural Postulates”, Mizan Law review, Vol. 5 No. 1, Spring, 2011, hlm. 143.

${ }^{6}$ A. Satrio, “Constitutional Retrogression in Indonesia ...,” hlm. 294.

${ }^{64}$ South China Morning Post menyebut Jokowi sebagai "little Soeharto"terkait banyaknya pendukung menduduki jabatan strategis, bisa dilihat di; Resty Woro Yuniar, "little suharto? Indonesian leader widodo's place Twitter personalities allies in key posts, sparking backlash", https://www.scmp.com/weekasia/politics/article/3109116/little-suharto-indonesian-leader-widodos-move-place-twitter, (diakses pada tanggal 21 November 2020 Pukul 12.35 wib)

65 Luthfi Widagdo Eddyono, "Penyelesaian sengketa kewenangan lembaga negara oleh Mahkamah Konstitusi", Jurnal Konstitusi, Volume 7, Nomor 3, Juni 2010, hlm. 38. 
dan bijaksana lepas dari kepentingan politik untuk mencegah terjadinya kemunduran konstitusi akibat solidnya hubungan kompromistis antar kedua cabang kekuasaan (Presiden dan DPR).

Keberadaan MK akhir-akhir ini justru sangat disayangkan karena menjadi lembaga yang sangat rawan menjadi objek politisasi, salah satunya pelanggaran kode etik yang dilakukan oleh Mantan Ketua Hakim MK Arief Hidayat yang bertemu salah satu anggota DPR dari Komisi III di sebuah hotel. ${ }^{66}$ Bukan hanya itu, hubungan antara Presiden dan DPR yang semakin solid akan berdampak pada pengisian jabatan di lembaga-lembaga independen lainnya misalnya Kapolri atau Panglima TNI yang rentan koruptif.

\section{Penutup}

Berdasarkan analisis di atas, penelitian ini menyimpulkan bahwa selama periode satu dekade terakhir, Indonesia telah mengalami constitutional retrogression sebagaimana yang disebut Huq dan Ginsburg yaitu menurunnya kualitas hukum dan ketangguhan institusi hukum. Hal tersebut didukung dengan data; pertama, adanya angka ambang batas yang cukup besar dalam pemilihan umum serentak, sehingga potensi pemusatan kekuasaan pada kedua cabang kekuasaan semakin besar; kedua, produk hukum yang dihasilkan Presiden dan DPR mencederai nilai demokrasi menyebabkan Indonesia masuk dalam kategori constitutional retrogression dan menjadi bukti tidak terciptanya fungsi checks and balances.

Upaya untuk mencegah terjadinya kemunduran konstitusi antara lain: pertama, menghapus atau mengecilkan angka presidential treshold jika pemilu tetap diadakan secara serentak; kedua, pemilu dengan sistem multipartai harus dilaksanakan dengan sistem proporsional dengan daftar terbuka; ketiga, MK harus menjadi lembaga yang imparsial untuk menengahi hubungan Presiden dan DPR yang rentan menimbulkan kesewenang-wenangan guna menghindari penyalahgunaan serta kemunduran konstitusi.

${ }^{66}$ Kristian Erdianto, Putusan Dewan Etik: Ketua MK Arief Hidayat Melanggar Kode Etik Ringan, https:// nasional.kompas.com/read/2018/01/16/14555591/putusan-dewan-etik-ketua-mk-arief-hidayatmelanggar-kode-etik-ringan?page $=$ all (diakses pada tanggal 5 Juli 2020 Pukul 14.07 WIB) 


\section{Daftar Pustaka}

\section{Buku}

Asshiddiqie, Jimly, Konstitusi dan Konstitusionalisme Indonesia, Cetakan Kedua, Sinar Grafika, Jakarta, 2010.

Konstitusi dan Konstitusionalisme Indonesia, Cetakan ketiga, Sinar Grafika, 2014.

- Perkembangan dan Konsolidasi Lembaga Negara Pasca Reformasi, Sinar Grafika, Cetakan Kedua, Jakarta Timur, 2012.

Atmadja, I Dewa Gede, Suko Wiyono dan Sudarsono, Teori Konstitusi dan konsep Negara Hukum, Setara Press, Malang, 2015.

Dicey, A.V., Pengantar Studi Hukum Konstitusi, Nusamedia, Cetakan kelima, Bandung, 2015

Erfandi, Parliamentary Threshold dan HAM dalam hukum tata negara Indonesia, Setara Press, Malang, 2014

Hariyono, dkk., Membangun Negara Hukum yang Bermartabat, Setara Press, Malang, 2013.

Magalatung, A. Salman, Desain kelembagaan negara pasca Amandemen UUD 1945, Gramata Publishing, Bekasi, 2016.

Mudde, C. \& Kaltwasser, C. R, Populism: A Very Short Introduction, Oxford University Press, New York, 2017.

Soekanto, Soerjono, Pengantar Penelitian Hukum, UI Press, Jakarta, 1986.

Soemantri, Sri, Hukum Tata Negara Indonesia, Cetakan Kedua, Remaja Rosdakarya, Bandung, 2015.

Suteki dan Galang Taufani, Metodologi Penelitian Hukum, PT RajaGrafindo, Depok, 2018.

\section{Jurnal}

Abdul Ghofar, "Problematika Presidential Threshold: Putusan Mahkamah Konstitusi dan Pengalaman di Negara Lain", Jurnal Konstitusi, Vol. 15, No. 3, September, 2018.

Ali Marwan, "Pengujian Peraturan Pemerintah Pengganti Undang-Undang (The Review Of The Government Regulation In Lieu Of Law)", Jurnal Legislasi Indonesia Vol. 13 No. 2, Juni, 2016.

A. Huq and Tom Gisnburg, "How to lose Constitutional Democracy", UCLA, Rev. $78,2018$.

A. Satrio, "kewenangan Mahkamah Konstitusi memutus perselisihan hasil pemilu sebagai bentuk judicialization of politics", Jurnal Konstitusi Vol. 12 No. 1, Maret, 2015. 
"Constitutional Retrogression in Indonesia under Presiden Joko widodo's Goverment; What can The Constitutional court do?" Constitutional Review, Vol. 4 No. 2, Desember, 2018.

Bisariyadi, "Yudisialisasi Politik dan Sikap Menahan Diri: Peran Mahkamah Konstitusi dalam Menguji Undang-Undang", Jurnal Konstitusi, Vol.12 No.3, September 2015.

Elise Nalbandian, "Sociological Jurisprudence: Roscoe Pound's Discussion on Legal Interests and Jural Postulates", Mizan Law review, Vol. 5 No. 1, Spring, 2011.

Pitoy, Hezky H. "Mekanisme Checks and Balances antara Presiden dan DPR dalam sistem pemerintahan Presidensial di Indonesia", Lex et Societatis Vol. II, No. 5, 2014.

J. Gurmann and S. Voigt, "Militan Constitutionalism- A promising Concept to make Constitutional Backsliding less likely?", Econstor, No. 25, 2019.

Luthfi Widagdo Eddyono, "Penyelesaian sengketa kewenangan lembaga negara oleh Mahkamah Konstitusi" Jurnal Konstitusi, Volume 7, Nomor 3, Juni 2010.

Pakpahan, Zainal Abidin "Pelaksanaan Pemilihan Umum Serentak pada Pemilihan Presiden dan Wakil Presiden, Anggota DPR, DPD dan DPRD sebagai implementasi Pelaksanaan sistem Demokrasi Pancasila", Jurnal Sosial ekonomi dan Humaniora, Vol. 5 No. 2, 2019.

Ran Hirschl "The Judicialization of Mega-Politics and the Rise of Political Courts", The Annual Review of Political Science, Vol. 11, 2008.

Saldi Isra, "Hubungan antara DPR dan Presiden", Jurnal konstitusi, Vol. 10, No. 3 , 2013.

Saldi Isra dan Feri Amsari, Perubahan Konstitusi melalui Tafsir Hakim MK, Jurnal Konstitusi, Vol. 1. No.1, November 2008.

\section{Majalah}

Faiz, Pan Mohammad, "Memaknai Salus populi Suprema Lex", Majalah Konstitusi No. 159, Mei 2020.

\section{Internet}

Andi Sarputra, "Khawatirnya pakar hukum hingga Anggota DPR terhadap Perppu Corona", https://news.detik.com/berita/d4991570/khawatirnya-pakar-hukum-hingga-anggota-dpr-terhadapperppu-corona/4, diakses pada tanggal 5 Juli 2020.

Bisma Septalisma, 5 Versi Draf Omnibus Law Ciptaker Usai Disahkan DPR https://www.cnnindonesia.com/nasional/20201013091525-32-557717/5versi-draf-omnibus-law-ciptaker-usai-disahkan-dpr, Diakses pada tanggal 19 November 2020. 
Budiarti Utami Putri, "Hormati Masyumi Reborn, Yusril cerita sulitnya partial Islam Cari Dana", https://nasional.tempo.co/read/1403825/hormatimasyumi-reborn-yusril-cerita-sulitnya-partai-islam-caridana/full?view=ok,Diakses pada tanggal 21 November 2020.

Fitria Chusna Farisa, "Perppu 1/2020 Terbit dan Disahkan dalam Satu Kali Masa Sidang DPR, Pemohon Nilai Bertentangan dengan UUD", https: / / nasional.kompas.com/read/2020/05/20/13435901/perppu-12020-terbit-dan-disahkan-dalam-satu-kali-masa-sidang-dprpemohon?page=all, Diakses pada tanggal 5 Juli 2020.

Kristian Erdianto, "Putusan Dewan Etik: Ketua MK Arief Hidayat Melanggar Kode Etik Ringan,", https://nasional.kompas.com/read/2018/01/16/ 14555591/putusan-dewan-etik-ketua-mk-arief-hidayat-melanggar-kodeetik-ringan?page=all, diakses pada tanggal 5 Juli 2020.

Resty Woro Yuniar, "little suharto? Indonesian leader widodo's place Twitter personalities allies in key posts, sparking backlash", https://www.scmp.com/week-asia/politics/article/3109116/littlesuharto-indonesian-leader-widodos-move-place-twitter, diakses pada tanggal 21 November 2020.

Robi Ardianto, "7 bahaya presidential threshold", https://www.alinea.id/ politik/7-bahaya-presidential-treshold-b1U3O9cPY, diakses pada tanggal 07 Juli 2020.

Teguh Firmansyah, "Ganti Perppu 1/2020 dengan UU APBN Perubahan", https:/ / m.republika.co.id/berita/q8xx78377/syarief-hasan-gantiperppu-12020-dengan-uu-apbn-perubahan, diakses pada tanggal 5 Juli 2020.

\section{Peraturan Perundang-undangan}

Undang-Undang Dasar Negara Republik Indonesia Tahun 1945.

Undang-Undang No. 7 tahun 2017 tentang Pemilu, LNRI Tahun 2017 Nomor 182, TLNRI Nomor 6109.

Undang-Undang No. 3 Tahun 2020 tentang Perubahan Atas UU 4 Tahun 2009 tentang Pertambangan Minerba, LNRI Tahun 2020 Nomor 147, TLNRI Nomor 6525.

Undang-Undang No. 7 Tahun 2020 Tentang Mahkamah Konstitusi, LNRI Tahun 2020 Nomor 216, TLNRI Nomor 6554.

Perppu No. 2 Tahun 2017 tentang Organisasi Kemasyarakatan, LNRI Tahun 2017 Nomor 138, TLNRI Nomor 6084.

Perppu No. 1 Tahun 2020 tentang Kebijakan Keuangan Negara Dan Stabilitas Sistem Keuangan Untuk Penanganan Pandemi Corona Virus Desease 2019 (Covid- 19) Dan/Atau Dalam Rangka Menghadapi Ancaman Yang Membahayakan Perekonomian Nasional Dan/Atau Stabilitas Sistem Keuangan, LNRI Tahun 2020 Nomor 87, TLNRI Nomor 6485. 